Review

\title{
Sclareol and cancer prevention: a mini-review
}

\section{Mohammad Sadegh Qadirifard', Zahra Arabpour', Sahar Afsahi', Fatemeh Sorkheh ${ }^{4}$, Seyedeh Negin Hamidpour ${ }^{5}$, Nazli Ahangarzadeh ${ }^{6}$, Bafrin Dabestani ${ }^{7}$, Arina Ansari ${ }^{8}$, Niloofar Deravi ${ }^{9}$}

1 Department of Nursing and Midwifery, Islamic Azad University, Tehran, Iran

2 Department of Nutrition, School of Health, Kerman University of Medical Sciences, Kerman, Iran

3 School of Medicine, Tehran University of Medical Sciences, Tehran, Iran

4 Student Research Committee, Babol University of Medical Sciences, Babol, Iran

5 School of Medicine, Shahrekord University of Medical Sciences, Shahrekord, Iran

6 School of Pharmacy, Ardabil University Of Medical Science, Ardabil, Iran

7 School of Allied Medical Sciences, Shahid Beheshti University of Medical Sciences, Tehran, Iran

8 Student Research Committee, School of Medicine, North Khorasan University of Medical Sciences, Bojnurd, Iran

9 Student Research Committee, School of Medicine, Shahid Beheshti University of Medical Sciences, Tehran, Iran

Correspondence:

Niloofar Deravi

SBUMS, Arabi Ave, Daneshjoo BIvd, Velenjak, Tehran, Iran postal code: 19839-63113 phone: +989193195717 e-mail: niloofarderavi@sbmu.ac.ir

Received: 17.11.2021

Accepted:

31.12.2021

DOI: 10.24292/01.OR.124311221 Copyright $\odot$ Medical Education. All rights reserved.

\section{ABSTRACT}

Sclareol is a labdane-type phytochemical compound that, due to its pharmacological attributes and historical use in herbal medicine, has attracted noteworthy attention. Numbers of research, mainly through testing on human and animal models, have demonstrated a wide range of effects, by which using sclareol may be considered as an important method in cancer prevention. By using the key words sclareol, cancer, neoplasia, we extracted the articles published up to September 2020 through search in PubMed, SID, ISI Web of Science, Scholar, and Scopus. This study aimed to summarize the research and studies on sclareol and its effects on cancer prevention and treatment.

Key words: scalreol, anticancer, herbal medicine 


\section{INTRODUCTION}

Cancer is a global health issue and a great socioeconomic burden that accounts for almost $13 \%$ of the mortality rate worldwide [1]. According to statics, it is estimated that 18.1 million cases and 9.6 million deaths of cancer have occurred during 2018, which by 2040, due to population growth and aging, can reach up to 29 million cancer cases [2, 3]. Genetic alterations are a key factor for developing cancer as they provide cells with features like limitless replicative potential, selective growth advantage, and altered response to anti-proliferative and apoptotic activities in favor of survival, invasion, and metastasis [4]. Targeting these hallmarks is considered as the base of chemotherapy (use of anti-cancer drugs) along with other cancer treatment methods such as surgery and radiotherapy $[4,5]$. Despite the use of chemotherapy as the main approach, its major side effects have raised interest in exploring more efficient drugs with less undesirable effects [6]. In contrast with synthesized chemical drugs, herbs and their derivatives have gained the attention of scientists for displaying promising profiles with low toxicity. Historically, natural compounds, consist of molecules with high-affinity, have been considered rich resources for drug discovery, and many of them exerted anti-cancer activity $[7,8]$. In this regard, sclareol (Labd-14-ene-8, 13-diol) is a practical chemical substance isolated mainly from the plant Salvia sclarea [9]. The molecule is used in a variety of aspects; it has been a subject of several studies for showing strong cytotoxic and cytostatic activities and being a potent anti-cancer agent [10-12]. Structurally, sclareol is a ditertiary alcohol belonging to labdane-type diterpenes with a stereochemistry-rich framework that is able to inhibit the mitochondrial and death receptor mediated tumor growth [13]. It has been reported that the sclareol is able to enhance the activity of some important and known anti-cancer drugs during the treatment like cisplatin doxorubicin, and etoposide [12]. Sclareol has the ability to modulate immune responses by affecting cytokine patterns [14]. The profile of sclareol activities stirred us to exploit its unique structure features for anti-cancer therapies and health improvements. The aim of this study was to outline the effects of sclareol on cancer prevention and treatment.

\section{METHODS}

This study reviewed and summarized data and information about sclareol and its effects on different types of cancers. In our study, the keywords searched were sclareol, cancer, and neoplasia. Searches were conducted from published articles in various journals up to September 2020 by using databases including ISI Web of Science, PubMed, Scopus, Scholar, SID.then, related articles were studied and reviewed.

\section{RESULTS}

\section{Effects of sclareol on colon cancer}

There is evidence that sclareol is effective in preventing colon cancer. Multiple studies have compared the level of anti-cancer activity of sclareol in different forms. Cosco et al. [15] showed that the anti-cancer effects of sclareol encapsulation with poly-lactic-co-glycolic acid (PLGA) on colon cancer cell lines (CaCo-2) are similar to those of free sclareol dissolved in ethanol. Mahaira et al. [16] observed the anti-cancer capability of sclareol by applying it on human colon cancer xenograft/mouse models, and results demonstrated that sclareol demolishes human tumor cells by halting cell cycle at the G1-phase pursued by the activation of caspases-8, -9 and -3 via a p53-independent mechanism leading to cell death. Also, the distinction between effects of two different sclareol forms, free and liposomal, has been reported in several studies. Dimas et al. [13] revealed that intraperitoneal (IP) injection of free sclareol was incapable of inhibiting the growth of xenograft HCT116 tumors in immunodeficient SCID mice. Conversely, IP injection of liposome-incorporated sclareol, with a particular schedule, induced suppression of tumor development by blocking tumor cells proliferation of which is supported by the evidence of the presence of cell proliferation-dependent nuclear protein (Ki-67) in thin sections of the tumor tissue. These findings indicate that liposomal sclareol may have chemotherapeutic potential for the therapy of colorectal and other types of cancers. Similar to these results, Hatziantoniou et al. [17] showed the combination of sclareol with liposomes compound of egg phosphatidylcholine and dipalmitoyl phosphatidylglycerol (with a certain molar ratio), in purpose to dominate its water insolubility and expanding appropriate formulations for in vivo efficiency, decreased the proliferation rate of human colon cancer tumors (HCT116) without any considerable side effects. Whereas in a study performed by Paradissis et al. [18], they suggested stronger anti-proliferative effect of free sclareol on HCT-116 cells but with much higher toxicity than liposome-incorporated sclareol. This can be explained by the higher and faster absorption of free sclareol into the cell than liposomal-incorporated type. Moreover, the level of sclareol in subcellular fractions demonstrated that liposomal sclareol is incorporated in crude membranes and then is delivered to cytosol and nuclei, while sclareol alone crosses straightly in the cytosol. All these findings suggest that liposome-incorporated sclareol is the better candidate agent than free form as it firmly acts as a growth inhibitor with low level of toxicity. 


\section{Effects of sclareol on buccal cancer}

Nallu et al. [19] investigated the antioxidant, anti-inflammatory, and anti-cancer activities of sclareol in buccal pouch carcinogenesis of 7, 12-dimethylbenz(a)anthracene (DMBA) evoked golden Syrian hamster. They observed that sclareol decreased tumor size and load, and enhanced antioxidant level, oxidative degradation of lipids, phase I and II detoxification enzymes, and has ameliorated the histopathological alterations in the course of carcinogenesis. Finally, this study represented that sclareol has the potential to prevent cancer progress in buccal tissue. Furthermore, Chinnaiyan et al. [20] reported that sclareol could restrain cancer favoring processes of hamster oral carcinogenesis by affecting notch signaling, a pathway that plays a main role in cell fate determination and differentiation and dysregulating the expression of involved genes. Besides, sclareol $(20 \mathrm{mg} / \mathrm{kg}$ body weight) enhanced the number of pro-apoptotic proteins and reduced anti-apoptotic proteins showing apoptosis through activation of caspase-3, and promoted apoptosis by impairing the regulation of cyclin D1 levels in tumor-bearing hamsters. Finally, the results of this study suggested the notch signaling pathway as a possible healing target for oral cancer.

\section{Effects of sclareol on cervical cancer}

In a study conducted by Li et al. [21] on anti-cancer activities of sclareol in HeLa cell line, sclareol exhibited cytotoxic effects on cervical cancer cells by halting the cell cycle at $\mathrm{S}$ phase, promoting apoptosis and blocking the mitogen-activated protein kinase/extracellular signal-regulated kinase (MAPK/ERK) signaling pathway. This pathway regulates differentiation, proliferation, and apoptosis [22], and constant activation of it can transform normal cells into cancer cells. In addition, sclareol also could increase chemosensitivity towards cisplatin on cancer cells [23]. In another study, Zhang et al. [22] revealed that sclareol could stimulate apoptosis and have an anti-proliferative effect on HeLa cells by increasing the caveolin-1 (Cav-1) expression and following decrease of copper-zinc superoxide dismutase (SOD) 1 level (SOD1 is down-regulated by Cav1 during lysosome mediated degradation) which, leads to enhanced sensitivity of HeLa cells towards bortezomib, an anti-cancer drug. Taken together, these data provide a potential approach for cervical cancer treatment and reducing drug-resistance.

\section{Effects of sclareol on lung cancer}

Multiple studies have been conducted on the effects of sclareol and its formulations on different lung cancer cells. In this regard, Chen et al. [24] studied the anti-cancer impacts of sclareol and its mechanisms on cell lines of human small cell lung carcinoma
(SCLC), in vitro and in mice models of tumor xenograft. In $\mathrm{H} 1688$ cells, sclareol significantly decreased cell survival, promoted cell cycle arrest at the G1 phase partly due to DNA damage showed by activation of ATR and Chk1 and H2AX phosphorylation, and subsequently induced apoptosis. Besides, in vivo observations of sclareol indicated that it could reduce tumor mass and size in an $\mathrm{H} 1688$ xenograft model. Eventually, they concluded that sclareol could be a new and effective medication used to treat patients diagnosed with SCLC. Also, Hamishehkar et al. [25] applied sclareol-SLNs (sclareol-loaded solid lipid nanoparticles) and plain sclareol on human lung epithelial tumor cells A549 to evaluate the production, characterization, and inhibitory effect of these compounds on cell proliferation. Results showed that treatment with plain sclareol exhibited its inhibitory effects on A549 growth after $24 \mathrm{~h}$ whereas cytotoxicity of slareol-SLNs and following growth inhibition was detected after $48 \mathrm{~h}$ and had higher impact on cells. Thus, sclareol nanoparticles could be utilized as an alternative for natural products with poor aqueous solubility that are currently used for cancer treatment. in another study conducted by Paradissis et al. [26] the effect of free sclareol form and its liposomal form on lung cancer cell lines $(\mathrm{H}-460)$ was explored, free sclareol exhibited higher toxicity as well as higher and faster absorption while despite of less toxcitiy liposomal form maintained its growth inhibition activity and can be used as a better anti-cancer agent than its free form. Moreover, treatment with sclareol could act as an adjuvant and sensitizer for other drugs as Chen et al. [27] observed in non-small cell lung cancer (NSCLC) that sclareol increased sensitivity to cisplatin in A549 cells and hypoxic stem-like lung cancer cells that used as cell models through decreasing the proteins promoting drug resistance and its upstream molecules including ERCC1, Snail, AKT and ERK. Hence improved the anti-cancer activity of cisplatin in A549 and stem-like cells of lung cancer and could be used as a potential cisplatin-based adjuvant for NSCLC treatment.

Astardzhieva et al. [28] investigated the preventive impact of tetralabdanes, formed by the chemical breakdown of the natural diterpene sclareol on the growth of experimentally induced lung metastases. Results showed that after intravenous administration of $25 \mathrm{mg} / \mathrm{kg}$ and $50 \mathrm{mg} / \mathrm{kg}$ sclareol-lactone, 30 minutes before the transplantation of lung carcinoma cells, the number of metastases decreased, respectively, by $37.5 \%$ and $33-63 \%$, whereas $100 \mathrm{mg} / \mathrm{kg}$ sclareol-lactone increased the number of metastases about 2-7\%. Under similar laboratory conditions, sclareol glycol given at a dose of $25 \mathrm{mg} / \mathrm{kg}$ and $50 \mathrm{mg} / \mathrm{kg}$ decreased lung metastases, respectively, by $38 \%$ and $26-61 \%$. Its administration in a dose of $100 \mathrm{mg} / \mathrm{kg}$ stimulated their formation with $62 \%$. 


\section{Effects of sclareol on leukemia}

In a study conducted by Kokkinopoulos et al. [29], sclareol was examined for its cytotoxic actions in four leukemic cell lines (two from B and two from $T$ lineage cell lines). Also, they observed the morphological changes and the type of sclareol-induced death in three cell lines. The results indicated that sclareol increased the population of cells arrested at the $\mathrm{G}(0 / 1)$ phase and could induce death in cells through time- and dose-dependent apoptosis. These cytotoxic outcomes were significant in all cell lines, excluding the human Burkitt lymphoma cell line Namalwa (immature B-cell), which showed resistance to doses lower than $50 \mathrm{mg} / \mathrm{ml}$. Besides, the effects of sclareol appeared to be associated with the maturity stage of $\mathrm{T}$ lineage, while there was no such relation in B lineage.

\section{Effects of sclareol on gastric cancer}

It is claimed in previous studies that triggering endoplasmic reticulum (ER) stress enhances the sensitivity of cells to anti-cancer drugs. In this regard, Aboutalebi et al. [30] evaluated the effect of sclareol on IRE-1)inositol-requiring enzyme (and PERK) pancreatic endoplasmic reticulum kinase (genes, involved in ER stress pathway, in human MKN-45 gastric cancer cells. Sclareol $(20 \mu \mathrm{M}, 40 \mu \mathrm{M}, 60 \mu \mathrm{M})$ increased the expression of IRE-1 and PERK, leading to induction of ER stress. Thereby, applying sclareol could be useful for controlling gastric cancer and also resolving drug resistance.

\section{Effects of sclareol on breast cancer}

Sclareol showed significant anti-cancer effects in several studies. It was able to inhibit DNA synthesis, induce cell cycle arrest at the G0/1 phase and apoptosis independent of p53 and remarkably reduce cell viability in human breast cancer cell lines MN1 and MDD2 derived from the parental cell line MCF7 $[32,33]$. Also, sclareol enhanced the expression of growth-inhibitors such as $\mathrm{p} 53$ and BAX while reduced the STAT3 phosphorylation and $\mathrm{BCL}-2$ expression. When $\mathrm{BCL}-2$ is over-expressed in cancer cells, it may inhibit pro-apoptosis signals allowing cancer cells to survive under stressful conditions [33]. Sclareol was able to suppress the act of IL- 6 in regulating the expression of apoptosis-related genes [33]. Moreover, sclareol could enhance the effect of cancer therapy due to its immunotherapeutic impacts against breast cancer. According to Noori et al. [33] study, direct intraperitoneal injection of sclareol significantly reduced the tumor volume and pro-proliferative cytokine IL-4 levels and increased IFN-y levels, a cytokine that inhibits tumor growth by several different mechanisms, and also reduced the number of splenic T regulatory cells. Furthermore, the combined administration of sclareol and other drugs has been found to be more potent in cancer treatment than when used separately. Based on several studies, sclareol enhanced the activity of known anti-cancer drugs, such as doxorubicin, etoposide, CIS platinum [32], and cyclophosphamide [33] against MCF7 breast cancer cell line. Besides, in a study conducted by Borges et al. [34], a nanostructured lipid carrier (NLC) co-loaded with DOX and SC (NLC-DOX-SC) exhibited more cytotoxicity and fewer side effects than DOX: SC. Besides these observations, it is reported that sclareol possess more efficient activities against breast cancer when it is used in the liposomal form due to less toxicity without affecting the anti-tumor activity [27] and when it is encapsulated with PLGA-hyaluronan ( $\mathrm{HA}$ ) complex due to the interaction of HAs with HA-receptors expressed on the surface of breast cancer cells [15].

\section{CONCLUSION}

The present review summarized and appraised the clinical evidence available on the effects of sclareol on cancer prevention and control. Based on the findings, it has been shown that sclareol possesses significant growth-inhibiting activities in a variety of cancers. These results can be taken into account in cancer studies. 
Table 1. Review of a comparative analytical studies of the effects of sclareol on cancer prevention.

\begin{tabular}{|c|c|c|c|c|c|}
\hline Author & Model & $\begin{array}{l}\text { Dose of } \\
\text { sclareol }\end{array}$ & Duration & Outcome & Mechanism \\
\hline Li et al. [21] & $\begin{array}{l}\text { Human HeLa } \\
\text { cervical cancer } \\
\text { cells }\end{array}$ & $\begin{array}{l}3 \mu \mathrm{M}, 6 \mu \mathrm{M}, \\
\text { and } 12 \mu \mathrm{M}\end{array}$ & $48 \mathrm{~h}$ & $\begin{array}{l}\text { Sclareol had anti-cancer activity } \\
\text { and enhanced the cisplatin } \\
\text { chemosensitivity of human HeLa } \\
\text { cervical cancer cells }\end{array}$ & $\begin{array}{c}\text { Sclareol targets PK/ERK } \\
\text { signaling pathway and } \\
\text { induces mitochondrial- } \\
\text {-mediated apoptosis }\end{array}$ \\
\hline $\begin{array}{l}\text { Zhang et al. } \\
\qquad \text { [22] }\end{array}$ & $\begin{array}{l}\text { HeLa cells, SW480, } \\
\text { SW620, HepG2, } \\
\text { and MCF-7 cancer } \\
\text { cell lines }\end{array}$ & $\begin{array}{l}5 \mu \mathrm{M}, 10 \mu \mathrm{M} \text {, } \\
\text { and } 20 \mu \mathrm{g} / \mathrm{ml}\end{array}$ & $\begin{array}{c}24 \mathrm{~h}, 48 \mathrm{~h} \text {, and } \\
72 \mathrm{~h}\end{array}$ & $\begin{array}{l}\text { Sclareol induced apoptosis and } \\
\text { inhibited cell proliferation of } \\
\text { the HeLa cells. It also enhanced } \\
\text { the anti-proliferative effect of } \\
\text { bortezomib }\end{array}$ & $\begin{array}{l}\text { Sclareol treatment may help } \\
\text { the down-regulation of SOD1 } \\
\text { due to lysosome-mediated } \\
\text { degradation by Cav1 }\end{array}$ \\
\hline $\begin{array}{l}\text { Borges et al. } \\
{[34]}\end{array}$ & $\begin{array}{l}\text { MDA-MB-231, } \\
\text { human breast } \\
\text { adenocarcinoma } \\
\text { cell line; 4T1, } \\
\text { murine breast } \\
\text { cancer cell line }\end{array}$ & $\begin{array}{c}0.94 \mu \mathrm{M}, \\
1.88 \mu \mathrm{M}, \\
3.75 \mu \mathrm{M}, \\
7.5 \mu \mathrm{M} \text {, and } \\
15 \mu \mathrm{M}\end{array}$ & $\begin{array}{l}1 \mathrm{~h}, 2 \mathrm{~h}, 4 \mathrm{~h}, \\
8 \mathrm{~h}, \text { and } 24 \mathrm{~h}\end{array}$ & $\begin{array}{l}\text { In vitro observation showed that } \\
\text { DOX : SC blend at the molar ratio } \\
1: 1.9 \text { have stronger synergistic } \\
\text { anti-cancer effects than the molar } \\
\text { ratio } 1: 7.5 \text {. } \\
\text { In comparison with free DOX, } \\
\text { NLC-DOX-SC exhibited more } \\
\text { anti-tumor and cytotoxic activity } \\
\text { in vitro }\end{array}$ & $\begin{array}{l}\text { SC encapsulated in } \\
\text { NLC-DOX-SC acts more } \\
\text { efficiently. Therefore, DOX } \\
\text { release can be controlled } \\
\text { better }\end{array}$ \\
\hline $\begin{array}{l}\text { Dimas et al. } \\
{[31]}\end{array}$ & $\begin{array}{l}\text { Human breast } \\
\text { cancer cell lines } \\
\text { MN1 and MDD2 }\end{array}$ & $\begin{array}{c}100 \mu \mathrm{M}, \\
50 \mu \mathrm{M}, \text { and } \\
10 \mu \mathrm{M}\end{array}$ & $\begin{array}{c}2 \mathrm{~h}, 4 \mathrm{~h}, 8 \mathrm{~h}, \\
16 \mathrm{~h}, \text { and } 48 \mathrm{~h}\end{array}$ & $\begin{array}{l}\text { Sclareol blocked cell cycle } \\
\text { progress and induced P53- } \\
\text {-dependent and independent } \\
\text { apoptosis in cells. It also } \\
\text { improved the cytotoxic actions } \\
\text { of cisplatinum, doxorubicin, and } \\
\text { etoposide against MDD2 breast } \\
\text { cancer cell line }\end{array}$ & $\begin{array}{l}\text { Treatment with sclareol } \\
\text { results in cell cycle arrest at } \\
\text { G1/S phase and enhances } \\
\text { the apoptotic stress induced } \\
\text { by DNA damaging drugs in } \\
\text { a p53-independent manner }\end{array}$ \\
\hline $\begin{array}{c}\text { Noori et al. } \\
\text { [33] }\end{array}$ & $\begin{array}{l}\text { Erythroleukemic } \\
\text { cell line (k562); } \\
\text { intraperitoneally } \\
\text { injected Sclareol }\end{array}$ & $35-75 \mu \mathrm{M}$ & $\begin{array}{c}24 \mathrm{~h}, 48 \mathrm{~h}, \text { and } \\
72 \mathrm{~h}\end{array}$ & $\begin{array}{l}\text { Sclareol inhibited the growth of } \\
\text { tumor cells and enhanced the } \\
\text { effect of cancer therapy }\end{array}$ & $\begin{array}{l}\text { Sclareol inhibits the growth } \\
\text { of tumor cells by decreasing } \\
\text { the number of splenic T } \\
\text { regulatory cells and the IL-4 } \\
\text { levels and increasing IFN- } \gamma \\
\text { levels }\end{array}$ \\
\hline $\begin{array}{c}\text { Mahaira et al. } \\
{[16]}\end{array}$ & $\begin{array}{l}\text { Human colon } \\
\text { cancer xenograft/ } \\
\text { mouse models; } \\
\text { HCT116 cells }\end{array}$ & $100 \mu \mathrm{M}$ & $\begin{array}{c}4 \mathrm{~h}, 8 \mathrm{~h}, \text { and } \\
16 \mathrm{~h}\end{array}$ & $\begin{array}{l}\text { Liposome-encapsulated } \\
\text { sclareol might be used as } \\
\text { a chemotherapy treatment of } \\
\text { colorectal and other cancers } \\
\text { regardless of the p53-status }\end{array}$ & $\begin{array}{l}\text { Sclareol induces growth } \\
\text { arrest at the G1-phase and } \\
\text { triggers the p53-independent } \\
\text { activation of caspases- } 8,-9 \text {, } \\
\text { and -3 which, leads to } \\
\text { apoptosis }\end{array}$ \\
\hline $\begin{array}{l}\text { Noori et al. } \\
{[14]}\end{array}$ & $\begin{array}{l}\text { Intra-tumorally } \\
\text { injected mice }\end{array}$ & $\begin{array}{c}7.85 \mu \mathrm{g} / \\
\text { mouse/day }\end{array}$ & 6 days & $\begin{array}{l}\text { The direct injection of sclareol } \\
\text { into tumors improved the anti- } \\
\text { cancer response of the immune } \\
\text { system and prevented tumor } \\
\text { progression }\end{array}$ & $\begin{array}{c}\text { Assessment of various } \\
\text { immunological parameters } \\
\text { such as splenocytes } \\
\text { proliferation, IFN- } \gamma \text { and IL-4 } \\
\text { release, CD4+CD25+FOXP3+ } \\
\text { Treg cells, and tumor size } \\
\text { indicates the anti-tumor } \\
\text { immune response }\end{array}$ \\
\hline $\begin{array}{c}\text { Dimas et al. } \\
{[10]}\end{array}$ & $\begin{array}{l}\text { human leukemic } \\
\text { cell lines }\end{array}$ & $\begin{array}{c}20 \mathrm{mg} / \mathrm{ml}^{\wedge}-1 \\
(\mathrm{IC} 50<20 \mathrm{mg} / \\
\mathrm{ml} \wedge-1 \text { in most } \\
\text { cell lines })\end{array}$ & $4 \mathrm{~h}$ & $\begin{array}{l}\text { The treatment with sclareol } \\
\text { induced leukemic cell lines death }\end{array}$ & $\begin{array}{l}\text { Sclareol could kill tumor cells } \\
\text { through a cell cycle phase- } \\
\text { specific mechanism, which } \\
\text { triggers the accumulation of } \\
\text { G }(0 / 1) \text { cells and apoptosis }\end{array}$ \\
\hline $\begin{array}{l}\text { Aboutalebi } \\
\text { et al. [30] }\end{array}$ & $\begin{array}{c}\text { gastric cancer cells } \\
\text { MKN-45 }\end{array}$ & $\begin{array}{c}20 \mu \mathrm{M}, 40 \mu \mathrm{M}, \\
60 \mu \mathrm{M}\end{array}$ & $5 \mathrm{~h}$ & $\begin{array}{l}\text { Sclareol doses in the range of } \\
20 \text { and } 60 \mu \mathrm{mol} \text { can be useful } \\
\text { for increasing the induction of } \\
\text { endoplasmic reticulum stress, } \\
\text { followed by tumor growth } \\
\text { inhibition }\end{array}$ & $\begin{array}{c}\text { Sclareol remarkably } \\
\text { increased the expression of } \\
\text { IRE-1 and PERK genes and } \\
\text { endoplasmic reticulum stress } \\
\text { response }\end{array}$ \\
\hline
\end{tabular}




\begin{tabular}{|c|c|c|c|c|c|}
\hline & $\begin{array}{c}\text { gastric cancer cells } \\
\text { MKN-45 }\end{array}$ & $\begin{array}{l}80 \mu \mathrm{M} \\
100 \mu \mathrm{M}\end{array}$ & $5 \mathrm{~h}$ & $\begin{array}{c}\text { Sclareol showed no significant } \\
\text { anti-tumor effect }\end{array}$ & $\begin{array}{l}\text { Sclareol decreased the } \\
\text { expression of IRE- } 1 \text { and PERK } \\
\text { genes and endoplasmic } \\
\text { reticulum stress response }\end{array}$ \\
\hline \multirow[t]{2}{*}{$\begin{array}{c}\text { Hamishehkar } \\
\text { et al. [25] }\end{array}$} & $\begin{array}{c}\text { A549 human lung } \\
\text { epithelial cancer } \\
\text { cells }\end{array}$ & $\begin{array}{l}42.47 \mathrm{mg} / \mathrm{g} \text { of } \\
\text { sclareol-SLNs }\end{array}$ & $48 \mathrm{~h}$ & $\begin{array}{l}\text { The sclareol-SLNs hindered A549 } \\
\text { growth and progress }\end{array}$ & $\begin{array}{c}\text { Sclareol-SLNs promoted } \\
\text { apoptotic and necrotic cell } \\
\text { death ( } 25.5 \% \text { early apoptosis, } \\
15 \% \text { late apoptosis, and } \\
15 \% \text { necrosis) }\end{array}$ \\
\hline & $\begin{array}{l}\text { A549 human lung } \\
\text { epithelial cancer } \\
\text { cells }\end{array}$ & $\begin{array}{l}42.47 \mathrm{mg} / \mathrm{g} \text { of } \\
\text { plain sclareol }\end{array}$ & $48 \mathrm{~h}$ & $\begin{array}{c}\text { The plain sclareol hindered A549 } \\
\text { growth and progress }\end{array}$ & $\begin{array}{l}\text { Plain sclareol promoted cell } \\
\text { death through } 36 \% \text { early } \\
\text { apoptosis (An+/Ple) and } 17 \% \\
\text { late apoptosis ( } \mathrm{An}+/ \mathrm{PI}+\text { ), and } \\
4 \% \text { necrosis (An-/PI+) }\end{array}$ \\
\hline $\begin{array}{l}\text { Nallu et al. } \\
\quad[20]\end{array}$ & $\begin{array}{l}\text { hamster buccal } \\
\text { pouch }\end{array}$ & $20 \mathrm{mg} / \mathrm{b} . w \mathrm{t}$ & 112 days & $\begin{array}{l}\text { Sclareol induced the suppression } \\
\text { of tumor growth }\end{array}$ & $\begin{array}{c}\text { Sclareol decreased tumor } \\
\text { size and load, and enhanced } \\
\text { antioxidant level, oxidative } \\
\text { degradation of lipids, phase I } \\
\text { and II detoxification enzymes, } \\
\text { and has ameliorated } \\
\text { the histopathological } \\
\text { alterations in the course of } \\
\text { carcinogenesis }\end{array}$ \\
\hline \multirow[t]{2}{*}{$\begin{array}{l}\text { Paradissis } \\
\text { et al. [18] }\end{array}$} & $\begin{array}{l}\text { HCT-116 cancer } \\
\text { cell lines }\end{array}$ & $\begin{array}{l}100 \mu \mathrm{M} \text { of free } \\
\text { sclareol }\end{array}$ & $96 \mathrm{~h}$ & $\begin{array}{l}\text { High toxicity by free sclareol was } \\
\text { demonstrated }\end{array}$ & $\begin{array}{c}\text { Sclareol caused growth } \\
\text { arrest at G0/1 phase induced } \\
\text { cell death by triggering the } \\
\text { apoptosis process }\end{array}$ \\
\hline & $\begin{array}{l}\text { HCT-116 cancer } \\
\text { cell lines }\end{array}$ & $\begin{array}{c}100 \mu \mathrm{M} \text { of } \\
\text { liposomal } \\
\text { sclareol }\end{array}$ & $96 \mathrm{~h}$ & $\begin{array}{l}\text { Treatement with liposomal } \\
\text { sclareol resulted in decreased } \\
\text { cytotoxicity yet preserved its } \\
\text { ability to inhibit tumor growth }\end{array}$ & $\begin{array}{c}\text { Sclareol caused growth } \\
\text { arrest at G0/1 phase induced } \\
\text { cell death by triggering the } \\
\text { apoptosis process }\end{array}$ \\
\hline \multirow[t]{4}{*}{$\begin{array}{l}\text { Paradissis } \\
\text { et al. [26] }\end{array}$} & $\begin{array}{l}\text { MCF-7 human } \\
\text { cancer } \\
\text { cell lines }\end{array}$ & $\begin{array}{l}100 \mu \mathrm{M} \text { of free } \\
\text { sclareol }\end{array}$ & $96 \mathrm{~h}$ & $\begin{array}{l}\text { High toxicity by free sclareol was } \\
\text { demonstrated }\end{array}$ & $\begin{array}{c}\text { Sclareol caused growth } \\
\text { arrest at } \mathrm{G} 0 / 1 \text { phase induced } \\
\text { cell death by triggering the } \\
\text { apoptosis process }\end{array}$ \\
\hline & $\begin{array}{l}\text { MCF-7 human } \\
\text { cancer } \\
\text { cell lines }\end{array}$ & $\begin{array}{l}100 \mu \mathrm{M} \text { of } \\
\text { liposomal } \\
\text { sclareol }\end{array}$ & $96 \mathrm{~h}$ & $\begin{array}{c}\text { Treatment with liposomal sclareol } \\
\text { resulted in decreased cytotoxicity, } \\
\text { yet preserved its ability to inhibit } \\
\text { tumor growth }\end{array}$ & $\begin{array}{c}\text { Sclareol caused growth } \\
\text { arrest at G0/1 phase induced } \\
\text { cell death by triggering the } \\
\text { apoptosis process }\end{array}$ \\
\hline & $\begin{array}{l}\text { H-460 human } \\
\text { cancer } \\
\text { cell lines }\end{array}$ & $\begin{array}{l}100 \mu \mathrm{M} \text { of free } \\
\text { sclareol }\end{array}$ & $96 \mathrm{~h}$ & $\begin{array}{l}\text { High toxicity by free sclareol was } \\
\text { demonstrated }\end{array}$ & $\begin{array}{c}\text { Sclareol caused growth } \\
\text { arrest at G0/1 phase induced } \\
\text { cell death by triggering the } \\
\text { apoptosis process }\end{array}$ \\
\hline & $\begin{array}{l}\text { H-460 human } \\
\text { cancer } \\
\text { cell lines }\end{array}$ & $\begin{array}{l}100 \mu \mathrm{M} \text { of } \\
\text { liposomal } \\
\text { sclareol }\end{array}$ & $96 \mathrm{~h}$ & $\begin{array}{c}\text { Treatment with liposomal sclareol } \\
\text { resulted in decreased cytotoxicity, } \\
\text { yet preserved its ability to inhibit } \\
\text { tumor growth }\end{array}$ & $\begin{array}{c}\text { Sclareol caused growth } \\
\text { arrest at G0/1 phase induced } \\
\text { cell death by triggering the } \\
\text { apoptosis process }\end{array}$ \\
\hline $\begin{array}{l}\text { Cosco et al. } \\
\text { [15] }\end{array}$ & $\begin{array}{l}\text { human breast } \\
\text { cancer cells } \\
\text { (MCF-7 and } \\
\text { MDA-MB468) }\end{array}$ & $\begin{array}{c}10 \mu \mathrm{M}, 20 \mu \mathrm{M}, \\
30 \mu \mathrm{M}, 40 \mu \mathrm{M}, \\
50 \mu \mathrm{M} \text { of } \mathrm{SCL} \\
\text { and SCL- } \\
\text {-loaded PLGA } \\
\text { nanoparticles }\end{array}$ & $\begin{array}{c}24 \mathrm{~h}, 48 \mathrm{~h} \text {, and } \\
72 \mathrm{~h}\end{array}$ & $\begin{array}{l}\text { Hyaluronic acid Coating of } \\
\text { (1.5 MDa) PLGA nanoparticles } \\
\text { improved the anti-tumor activity } \\
\text { of the encapsulated sclareol }\end{array}$ & $\begin{array}{l}\text { HAs interact with } \\
\text { HA-receptors expressed on } \\
\text { the surface of breast cancer } \\
\text { cells }\end{array}$ \\
\hline $\begin{array}{l}\text { Cosco et al. } \\
\text { [15] }\end{array}$ & $\begin{array}{l}\text { human colon } \\
\text { carcinoma cells } \\
\text { (CaCo- } 2)\end{array}$ & $\begin{array}{l}10,20,30,40 \\
50 \mu \mathrm{M} \text { of } \mathrm{SCL} \\
\text { and SCL- } \\
\text {-loaded PLGA } \\
\text { nanoparticles }\end{array}$ & $\begin{array}{c}24 \mathrm{~h}, 48 \mathrm{~h} \text {, and } \\
72 \mathrm{~h}\end{array}$ & $\begin{array}{c}\text { The anti-cancer effects of sclareol } \\
\text { encapsulation with PLGA are } \\
\text { similar to those of free sclareol } \\
\text { dissolved in ethanol }\end{array}$ & Not mentioned \\
\hline
\end{tabular}




\begin{tabular}{|c|c|c|c|c|c|}
\hline $\begin{array}{c}\text { Dimas et al. } \\
\text { [13] }\end{array}$ & $\begin{array}{l}\text { human colon } \\
\text { cancer } \\
\text { HCT116 cells }\end{array}$ & $\begin{array}{c}100 \mu \mathrm{M} \text { of } \\
\text { sclareol (in } \\
\text { vitro) } \\
50 \mathrm{mg} / \mathrm{kg} \text { of } \\
\text { free sclareol }\end{array}$ & $\begin{array}{c}8 \text { h, } 16 \text { h, } 24 \text { h } \\
\text { (in vitro) } \\
5 \text { consecutive } \\
\text { days (in vivo) }\end{array}$ & $\begin{array}{c}\text { In vitro administration of free } \\
\text { scalerol showed significant anti- } \\
\text { tumor and cytotoxic activities, } \\
\text { while intraperitoneal (IP) injection } \\
\text { of free sclareol was incapable } \\
\text { of inhibiting the growth of } \\
\text { xenograft HCT116 tumors in } \\
\text { immunodeficient SCID mice }\end{array}$ & $\begin{array}{c}\text { In vitro administration of free } \\
\text { scalerol led to impairment } \\
\text { of DNA synthesis, blockage } \\
\text { of cell cycle at the G1 } \\
\text { phase, and the induction of } \\
\text { apoptosis through caspase-8, } \\
-9 \text { activation, PARP cleavage, } \\
\text { and DNA damage }\end{array}$ \\
\hline $\begin{array}{c}\text { Dimas et al. } \\
\text { [13] }\end{array}$ & $\begin{array}{l}\text { human colon } \\
\text { cancer } \\
\text { HCT116 cells }\end{array}$ & $\begin{array}{l}275 \mathrm{mg} / \mathrm{kg} \\
\text { of liposomal } \\
\text { sclareol }\end{array}$ & $\begin{array}{l}5 \text { consecutive } \\
\text { days (in vivo) }\end{array}$ & $\begin{array}{c}\text { IP injection of liposome- } \\
\text {-incorporated sclareol, } \\
\text { suppressed tumor development }\end{array}$ & $\begin{array}{l}\text { Liposomal sclareol directly } \\
\text { blocked tumor cells } \\
\text { proliferation }\end{array}$ \\
\hline
\end{tabular}

DOX - doxorubicin (an anthracycline drug); NLC-DOX-SC: nanostructured lipid carriers-doxorubicin-sclare; SC - sclareol.

\section{References}

1. Sener SF, Grey N. The global burden of cancer. J Surg Oncol. 2005; 92.1-3. http://doi.org/10.1002/jso.20335.

2. Bray F, Ferlay J, Soerjomataram I et al. Global cancer statistics 2018: GLOBOCAN estimates of incidence and mortality worldwide for 36 cancers in 185 countries [published correction appears in CA Cancer J Clin. 2020; 70(4): 313]. CA Cancer J Clin. 2018; 68(6): 394-424. http://doi.org/10.3322/ caac.21492.

3. Ferlay J, Colombet M, Soerjomataram I et al. Estimating the global cancer incidence and mortality in 2018: GLOBOCAN sources and methods. Int J Cancer. 2019; 144(8): 1941-53. http://doi.org/10.1002/ijc.31937.

4. Luo J, Solimini NL, Elledge SJ. Principles of cancer therapy: oncogene and non-oncogene addiction. Cell. 2009; 136(5): 823-37. http://doi.org/10.1016/ j.cell.2009.02.024. Erratum in: Cell. 2009; 138(4): 807.

5. Rauf A, Imran M, Butt MS et al. Resveratrol as an anti-cancer agent: A review. Crit Rev Food Sci Nutr. 2018; 58(9): 1428-47.

6. Evans BE, Rittle KE, Bock MG et al. Methods for drug discovery: development of potent, selective, orally effective cholecystokinin antagonists. J Med Chem. 1988; 31(12): 2235-46.

7. Swinney DC, Anthony J. How were new medicines discovered? Nat Rev Drug Discov. 2011; 10(7): 507-19. http://doi.org/10.1038/nrd3480.

8. Newman DJ, Cragg GM. Natural products as sources of new drugs over the 30 years from 1981 to 2010. J Nat Prod. 2012; 75(3): 311-35.

9. Ulubelen A, Sönmez U, Topcu G et al. An abietane diterpene and two phenolics from Salvia forskahlei. Phytochemistry. 1996; 42(1): 145-7.

10. Dimas K, Kokkinopoulos D, Demetzos C et al. The effect of sclareol on growth and cell cycle progression of human leukemic cell lines. Leuk Res. 1999; 23(3): 217-34.

11. Dimas K, Demetzos C, Vaos V et al. Labdane type diterpenes down-regulate the expression of c-Myc protein, but not of Bcl-2, in human leukemia T-cells undergoing apoptosis. Leuk Res. 2001; 25(6): 449-54.

12. Dimas K, Papadaki M, Tsimplouli C et al. Labd-14-ene-8, 13-diol (sclareol) induces cell cycle arrest and apoptosis in human breast cancer cells and enhances the activity of anti-cancer drugs. Biomed Pharmacother. 2006; 60(3): 127-33.

13. Dimas $K$, Hatziantoniou S, Tseleni $S$ et al. Sclareol induces apoptosis in human HCT116 colon cancer cells in vitro and suppression of HCT116 tumor growth in immunodeficient mice. Apoptosis. 2007; 12(4): 685-94.

14. Noori S, Hassan ZM, Mohammadi M et al. Sclareol modulates the Treg intra-tumoral infiltrated cell and inhibits tumor growth in vivo. Cell Immunol. 2010; 263(2): 148-53.

15. Cosco D, Mare R, Paolino D et al. Sclareol-loaded hyaluronan-coated PLGA nanoparticles: Physico-chemical properties and in vitro anti-cancer features. Int J Biol Macromol. 2019; 132: 550-7.

16. Mahaira LG, Tsimplouli C, Sakellaridis $\mathrm{N}$ et al. The labdane diterpene sclareol (labd-14-ene-8, 13-diol) induces apoptosis in human tumor cell lines and suppression of tumor growth in vivo via a p53-independent mechanism of action. Eur J Pharmacol. 2011; 666(1-3): 173-82.

17. Hatziantoniou S, Dimas K, Georgopoulos A et al. Cytotoxic and anti-tumor activity of liposome-incorporated sclareol against cancer cell lines and human colon cancer xenografts. Pharmacol Res. 2006; 53(1): 80-7.

18. Paradissis A, Hatziantoniou S, Georgopoulos A et al. Liposomes modify the subcellular distribution of sclareol uptake by HCT-116 cancer cell lines. Biomed Pharmacother. 2007; 61(2-3): 120-4.

19. Nallu A, Kathiresan S, Kathiresan S. Tumour preventive potential of sclareol on 7, 12 dimethylbenz [a] anthracene (DMBA) induced hamster buccal pouch carcinogenesis. Int J Res Pharm Sci. 2020; 11(1): 1182-91.

20. Chinnaiyan A, Nallu A, Kathiresan S. Sclareol induces apoptosis and inhibits notch signaling in hamster oral carcinogenesis. AACR; 2020.

21. Li W, Ping Z, Xuemei G et al. Naturally Occurring Sclareol Diterpene Augments the Chemosensitivity of Human Hela Cervical Cancer Cells by Inducing Mitochondrial Mediated Programmed Cell Death, S-Phase Cell Cycle Arrest and Targeting Mitogen-Activated Protein Kinase (MAPK)/Extracellular-Signal-Regulated Kinase (ERK) Signaling Pathway. Med Sci Monit. 2020; 26: e920248-1.

22. Zhang T, Wang T, Cai P. Sclareol inhibits cell proliferation and sensitizes cells to the anti-proliferative effect of bortezomib via upregulating the tumor suppressor caveolin-1 in cervical cancer cells. Mol Med Rep. 2017; 15(6): 3566-74.

23. Rubinfeld H, Seger R. The ERK cascade as a prototype of MAPK signaling pathways. MAP Kinase Signaling Protocols: Springer; 2004: 1-28.

24. Chen HL, Gong JY, Lin SC et al. Effects of Sclareol Against Small Cell Lung Carcinoma and the Related Mechanism: In Vitro and In Vivo Studies. Anticancer Res. 2020; 40(9): 4947-60. 
25. Hamishehkar H, Bahadori MB, Vandghanooni S et al. Preparation, characterization and anti-proliferative effects of sclareol-loaded solid lipid nanoparticles on A549 human lung epithelial cancer cells. J Drug Deliv Sci Technol. 2018; 45: 272-80.

26. Paradissis A, Hatziantoniou S, Georgopoulos A et al. Uptake Studies of Free and Liposomal Sclareol by Mcf-7 and H-460 Human Cancer Cell Lines. Nanomaterials and Nanosystems for Biomedical Applications: Springer; 2007: 125-33.

27. Chen SY. Sclareol Enhance Susceptibility to Cisplatin in Non-Small Cell Lung Cancer. Faseb J. 2016; 30 (suppl 1): 1193.11-1193.11. http://doi.org/10.1096/ fasebj.30.1_supplement.1193.11.

28. Astardzhieva Z, Stoichkov IJEMiM. The effect of sclareol lactone and sclareol glycol on artificially induced lung metastases of Lewis lung carcinoma (a preliminary report). 1990; 29(3): 58-61.

29. Dimas K, Kokkinopoulos D, Demetzos C et al. The effect of sclareol on growth and cell cycle progression of human leukemic cell lines. Leuk Res. 1999; 23(3): 217-34.

30. Aboutalebi E, Dolatkhah H, Sakhinia E et al. Investigating the effect of Sclareol on IRE-1 and PERK genes The pathway of reticulandaplasmic system stress in gastric cancer cells MKN-45. International Journal of Research in Applied and Basic Medical Sciences. 2020; 6(1): 32-44.

31. Dimas K, Papadaki M, Tsimplouli C et al. Labd-14-ene-8,13-diol (sclareol) induces cell cycle arrest and apoptosis in human breast cancer cells and enhances the activity of anti-cancer drugs. Biomed Pharmacother. 2006; 60(3): 127-33.

32. Afshari $\mathrm{H}$, Nourbakhsh $\mathrm{M}$, Salehi $\mathrm{N}$ et al. STAT3-mediated apoptotic-enhancing function of sclareol against breast cancer cells and cell sensitization to cyclophosphamide. Iran J Pharm Res. 2020; 19(1): 398-412.

33. Noori S, Mohammad Hassan Z, Salehian O. Sclareol Reduces CD4+ CD25+ FoxP3+ T-reg cells in a breast cancer model in vivo. Iran J Immunol. 2013; 10(1): 10-21.

34. Borges GSM, de Oliveira Silva J, Fernandes RS et al. Sclareol is a potent enhancer of doxorubicin: Evaluation of the free combination and co-loaded nanostructured lipid carriers against breast cancer. Life Sci. 2019; 232: 116678.

Authors' contributions:

Niloofar Deravi: study concept, design, reviewing and analysis of the data, final review and editing; Mohammad Sadegh Qadirifard: study concept, design, reviewing and analysis of the data; Zahra Arabpour:

contribution of the development of the study, abstract data, and prepare the manuscript; S.Afsahi: contribution of the development of the study, abstract data, and prepare the manuscript; Fatemeh Sorkheh: critical revision of the manuscript for important intellectual content;

Seyedeh Negin Hamidpour: critical revision of the manuscript for important intellectual content; Nazli Ahangarzadeh: critical revision of the manuscript for important intellectual content; Bafrin Dabestani: checking the study body form and characterizing the data; Arina Ansari: checking the study body form and characterizing the data.

Conflict of interests: The authors have disclosed no conflicts of interest.

Financial support:

This research has not received any specific grant from public funding agencies, commercial or non-profit.

Ethics:

The authors had full access to the data and take full responsibility for its integrity.

All authors have read and agreed with the content of the manuscript as written

The paper complies with the Helsinki Declaration, EU Directives and harmonized requirements for biomedical journals. 